\title{
Pesticides in streams in part of the Upper Mississippi River Basin, Minnesota and Wisconsin, 1974-94
}

Analysis of historical pesticide information by the National Water-Quality Assessment (NAWQA) Program indicates that land use and pesticide use affect detections of pesticides in streams in part of the Upper Mississippi River Basin (UMIS). Agricultural pesticide use was greatest in the Minnesota River Basin. Greater than twenty-seven times more herbicides than insecticides were used for agriculture. Pesticide detections were greatest in or downstream of agricultural and urban areas. Herbicides were detected most frequently in stream water; whereas, organochlorine insecticides were detected most frequently in streambed sediment. Most concentrations were below levels considered harmful to human and aquatic health.

\section{National Water-Quality Assessment Program}

In 1994, the U.S. Geological Survey's NAWQA Program began a study in the Upper Mississippi River Basin (fig. 1). One of the goals of the program is to document the quality of surface water of the Nation and to explain natural and human factors affecting water quality. An initial objective of the UMIS study was to summarize existing information on pesticides in streams. Data from 1974-94 were obtained from the Metropolitan Council Environmental Services,

Minnesota Department of Agriculture, Minnesota Department of Health, Minnesota Pollution Control Agency, Wisconsin Department of Natural Resources, U. S. Army Corps of Engineers, and the U.S. Geological Survey. The pesticides analyzed varied by agency, year, and medium sampled. For details, refer to Fallon and others (1997), the report from which this fact sheet is derived.

The UMIS study unit (fig. 1) encompasses an area of about 47,000 square miles, and includes the drainage area of the Mississippi River from its source to the outlet of Lake Pepin. Land cover includes agriculture, forests, wetlands, lakes, and the Twin Cities (Minneapolis and St. Paul) metropolitan area (TCMA). This fact sheet summarizes analyses of pesticide samples collected in a focused study area shown in fig. 1 .

\section{Concerns about pesticides in streams}

Pesticides can have toxic, mutagenic, or carcinogenic effects in humans and aquatic life (U.S. Environmental Protection Agency, 1994). Pesticides transform into other compounds that also can be toxic.

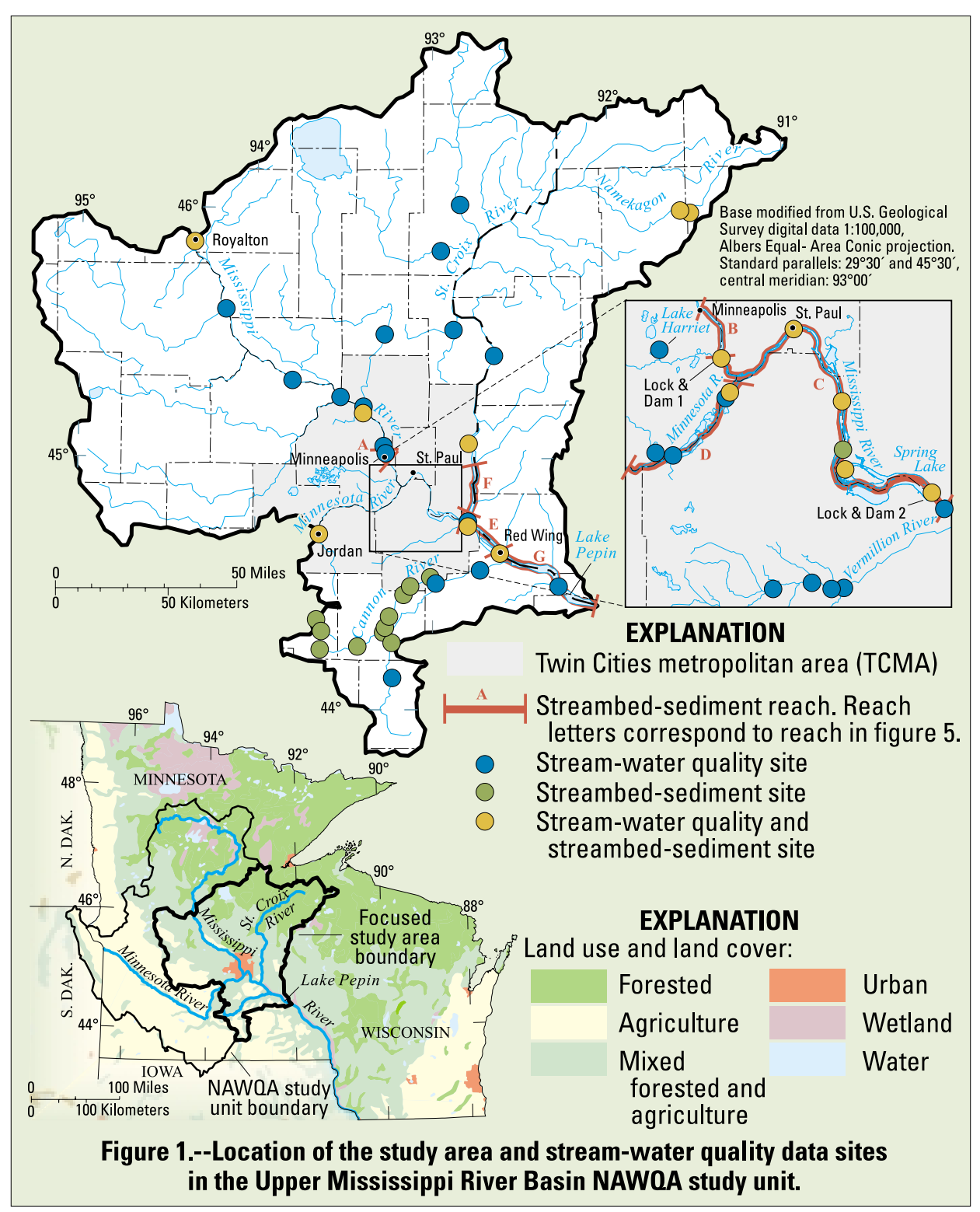

Streams can transport pesticides to ground water and lakes where physical conditions allow many pesticides to persist longer than in streams. Removing pesticides from drinking-water sources requires carbon filtration or ozonation equipment (Miltner and others, 1989). 


\section{Sources of pesticides in the Upper Mississippi River Basin study unit}

Precise accounting of pesticide use is not possible because pesticide sales are not reported for commercial, industrial, and residential uses. However agriculture use estimates, which account for three-fourths of national pesticide use (Aspelin, 1994), are available.

Agricultural pesticide use data were compiled for the entire study unit because pesticides can be transported by streamflow and atmospheric deposition into the focused study area. Data from Gianessi and Puffer (1991 and 1992) were used as estimates of 1989 application rates for the 10 most-used herbicides and insecticides (fig. 1 and table 2). The highest rates of pesticide use occurred in the Minnesota River Basin.

Greater than 27 times more herbicides than insecticides were used, with approximately 16.9 million pounds of active herbicide ingredients applied annually in total herbicide use (16 compounds). Herbicides often are applied at greater quantities, more frequently, and to broader areas than insecticides. Most were used in corn and soybean fields. Herbicide use data for urban and forested areas are limited to local surveys, product registrations, and inferences from national studies. A survey indicated that the mostused herbicide on TCMA lawns and gardens was 2,4-D, with application rates similar to those of agriculture (Creason and Runge, 1992). Consequently, agricultural herbicide use may be greater than urban use only because there is more agricultural land use. Herbicide use data for forests are not available, but use is thought to be low because only about two percent of forests in the U.S. are treated annually (Larson and others, 1997).

About 605,000 pounds per year of active insecticide ingredients (10 compounds) were applied for agriculture in the study unit. No domestic insecticide use data are available, but five insecticides used in agriculture (chlorpyrifos, malathion, permethrin, diazinon, and carbaryl) also are used domestically in the U.S. (Whitmore and others, 1992).

Insecticides used in forested areas of the study unit include five used in agriculture

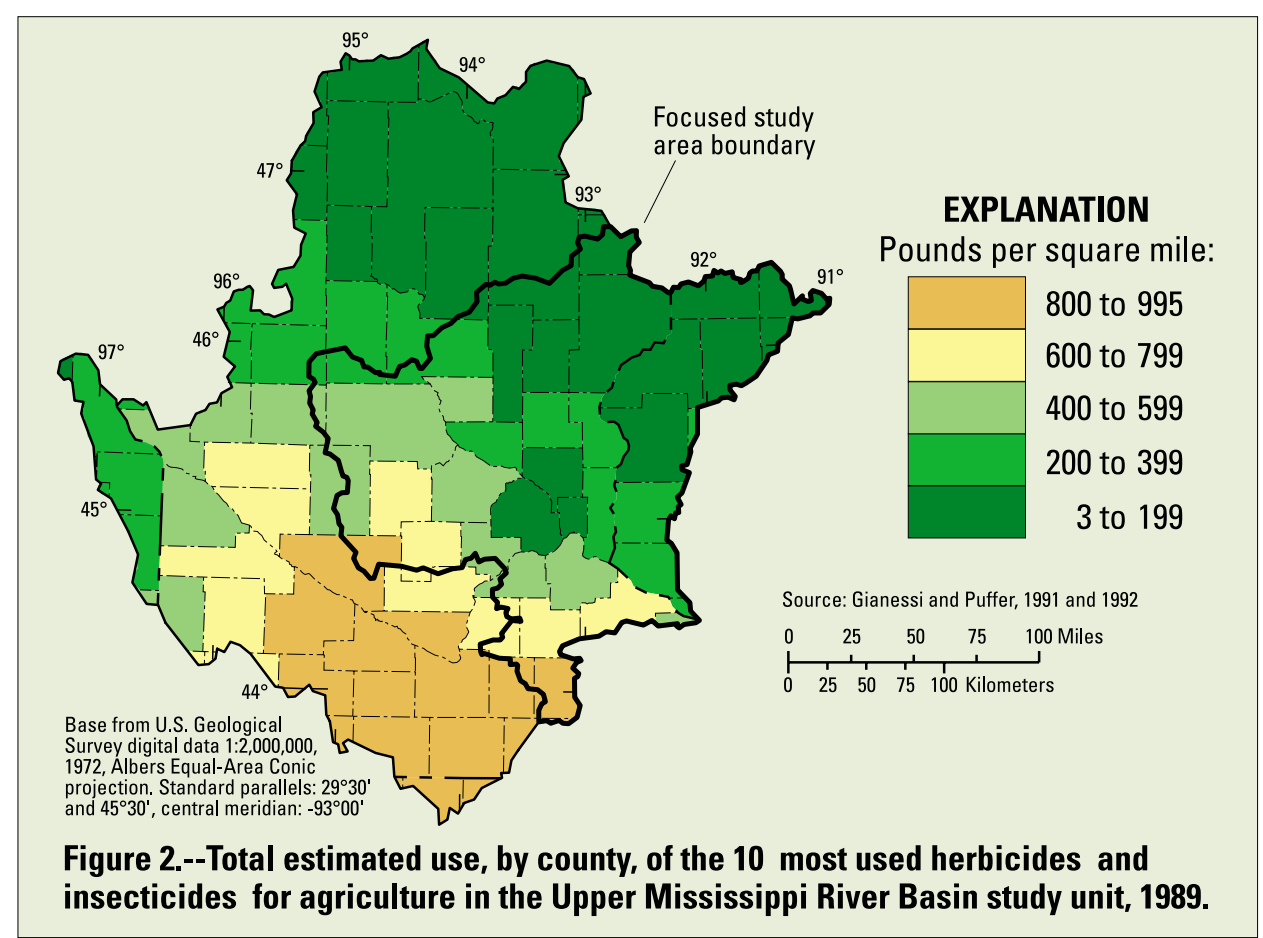

Table 1: Quantities of the ten most-used herbicides and insecticides for agriculture in 1989 in the Upper Mississippi River Basin study unit (Gianessi and Puffer, 1991 and 1992).

\begin{tabular}{r|l|r|r|r} 
Rank & Herbicide & \multicolumn{1}{c|}{$\begin{array}{c}\text { Quantity applied } \\
\text { (thousands of pounds) }\end{array}$} & Insecticide & $\begin{array}{c}\text { Quantity applied } \\
\text { (thousands of pounds) }\end{array}$ \\
\hline 1 & EPTC & 4,490 & Carbofuran & 200. \\
\hline 2 & Alachlor & 2,400 & Chlorpyrifos & 184 \\
\hline 3 & Cyanazine & 1,650 & Aldicarb & 110. \\
\hline 4 & Trifluralin & 1,590 & Fonofos & 53.1 \\
\hline 5 & Acetochlor (1994) & 1,260 & Methyl parathion & 44.9 \\
\hline 6 & Atrazine & 1,130 & Malathion & 7.78 \\
\hline 7 & 2,4-D & 1,080 & Terbufos & 5.02 \\
\hline 8 & Butylate & 612 & Permethrin & 4.02 \\
\hline 9 & Bentazon & 494 & Diazinon & 0.48 \\
\hline 10 & Dicamba & 483 & Carbaryl & 0.06 \\
\hline
\end{tabular}

* Acetochlor was reregistered in 1993 for weed control on corn and is included for approximate comparison to other herbicide usages.

as well (carbofuran, methyl parathion, malathion, permethrin, and carbaryl).

In addition to current insecticides, many organochlorine (OC) insecticides were used in the 1950's to 1970's. Most were used for agriculture, but some, such as DDT, chlordane, heptachlor, and lindane, also were used in urban areas to control mosquitoes and termites, and to treat lumber (Sine, 1993; Majewski and Capel, 1995). Use of these OC insecticides has been restricted or banned in the U.S. because of concerns about their toxicity, bioaccumulation, persistence, and reduced effectiveness.

\section{Pesticides in streams and streambed sediment frequently detected at low concentrations}

Herbicides were the most frequently analyzed and detected type of pesticide in water. Insecticides were rarely analyzed or detected. In streambed sediment, OC insecticides were the most frequently analyzed and detected type of pesticides. Details of pesticides analyzed are given in Fallon and others (1997).

\section{Herbicides in streams}

The thirty-nine stream-water quality sites sampled by various agencies were 
located primarily downstream of agricultural and urban areas (fig. 1).

Because data are from many agencies and periods, the number of herbicides and insecticides analyzed in stream-water samples ranged from 6 to 54. Insecticides were rarely detected and are not discussed.

Detection frequencies of the most frequently detected herbicides are shown in fig. 3. Concentrations were censored below 0.2 microgram per liter $(\mu \mathrm{g} / \mathrm{L})$ to eliminate bias from varying analytical detection limits. Detection frequencies would almost double if data were not censored. The four most frequently detected herbicides (atrazine, cyanazine, metolachlor, and alachlor) are among the ten most used for agriculture and are not registered for urban use, suggesting that detections are related to agricultural usage. Furthermore, these four herbicides typically are applied to the soil surface making them vulnerable to surface runoff; whereas, the other six of the ten most used typically are incorporated in the soil.

These four herbicides are triazine or acetanilide compounds, suggesting that detection frequencies are related to pesticide type. These compounds persist longer in surface water than other types currently used in the largest quantities (EPTC, trifluralin, butylate, and bentazon).

Detection frequencies also are related to land use. Detection frequencies were greatest in streams draining areas of intense agricultural and urban land use. Although usage of most of the herbicides detected in the focused study area is restricted to agriculture, agricultural herbicides were detected regularly in a completely urbanized watershed (Lake Harriet in Minneapolis) and in rain samples in the watershed, indicating herbicides are transported atmospherically from agricultural areas and deposited in other areas (Capel and others, 1998). Herbicides also were detected in forested watersheds, although these herbicides may have originated from agricultural areas in those watersheds.

Herbicide concentrations were generally less than $1.0 \mu \mathrm{g} / \mathrm{L}$. Only two samples, from urban storm-water drainage to Lake Harriet, had atrazine concentrations greater than $3.0 \mu \mathrm{g} / \mathrm{L}$. Concentrations in agricultural streams were greatest in June and July; whereas, concentrations in storm-water drainage to Lake Harriet remained elevated (1-2 orders of magnitude greater than detection limits) throughout the summer. Herbicides may be applied more frequently and for longer periods in urban areas than in agricultural areas (Wotzka and others, 1994).

Consequently, land use and timing of application affects seasonal patterns in concentrations.

\section{Organochlorine insecticides in streambed sediment}

$\mathrm{OC}$ insecticides were the most frequently analyzed and detected pesticides in streambed sediment, based on samples from 27 sites and 7 stream reaches (fig. 1). Most sampling occurred from 1975-85.

Three OC insecticides ( $p, p$ '-DDT, heptachlor, and $\gamma$-BHC (Lindane)) and related compounds ( $p, p$ '-DDD, $p, p$ '-DDE, heptachlor epoxide, $\alpha$-BHC, and $\delta$-BHC) accounted for almost two-thirds of the types of OC insecticides detected and of the total number of detections (fig. 4). The most frequently detected OC compounds were $p, p$-DDT and its transformation products. Chlordane was the most frequently detected parent compound. Concentrations generally were less than 10 micrograms per kilogram. Detections occurred throughout the period of analysis (1974-94), but the largest concentrations were detected before 1988 .

The types of OC insecticides detected increased in successive downstream reaches of the Mississippi, Minnesota, and St. Croix Rivers through the TCMA (fig. 5). The most OC compounds were detected in Pool 2 of the Mississippi River (reach C). Pool 2 had detections of each of the eight OC insecticides that were analyzed by all agencies. OC detections in Pool 2 reflect both urban and agricultural sources, because samples were collected downstream of small urban tributaries in the TCMA and downstream of the Minnesota River, which drains predominantly agricultural land.

Similarly, the frequency of OC detections increased in river reaches of the Mississippi, Minnesota, and St. Croix Rivers through the TCMA. These results indicate that both urban and agricultural areas are sources of OC insecticides.

\section{Implications of pesticide use on water quality}

Pesticides were detected in streams throughout the focused study area. Herbicide detection frequencies were similar in urban and agricultural areas. Forested areas had the lowest concentrations and fewest detections. More types and greater detection frequencies of OC insecticides were found in river reaches in urban areas than in agricultural areas.

Few samples had concentrations that exceeded U.S. Environmental Protection Agency annual maximum contaminant levels (MCL) for drinking water or freshwater-quality criteria for protection of aquatic life. Two stream samples from storm-water drainage to Lake Harriet in Minneapolis had atrazine concentrations of 3.6 and $3.8 \mu \mathrm{g} / \mathrm{L}$, exceeding the MCL of $3.0 \mu \mathrm{g} / \mathrm{L}$ (U.S. Environmental Protection Agency, 1994). Trace concentrations (less than $0.06 \mu \mathrm{g} / \mathrm{L}$ ) of OC insecticides exceeded USEPA chronic freshwater criteria (Nowell and Resek, 1994) in water samples from the Mississippi, Minnesota, St. Croix, and Vermillion Rivers in 1981 and 1990. Therefore, concentrations

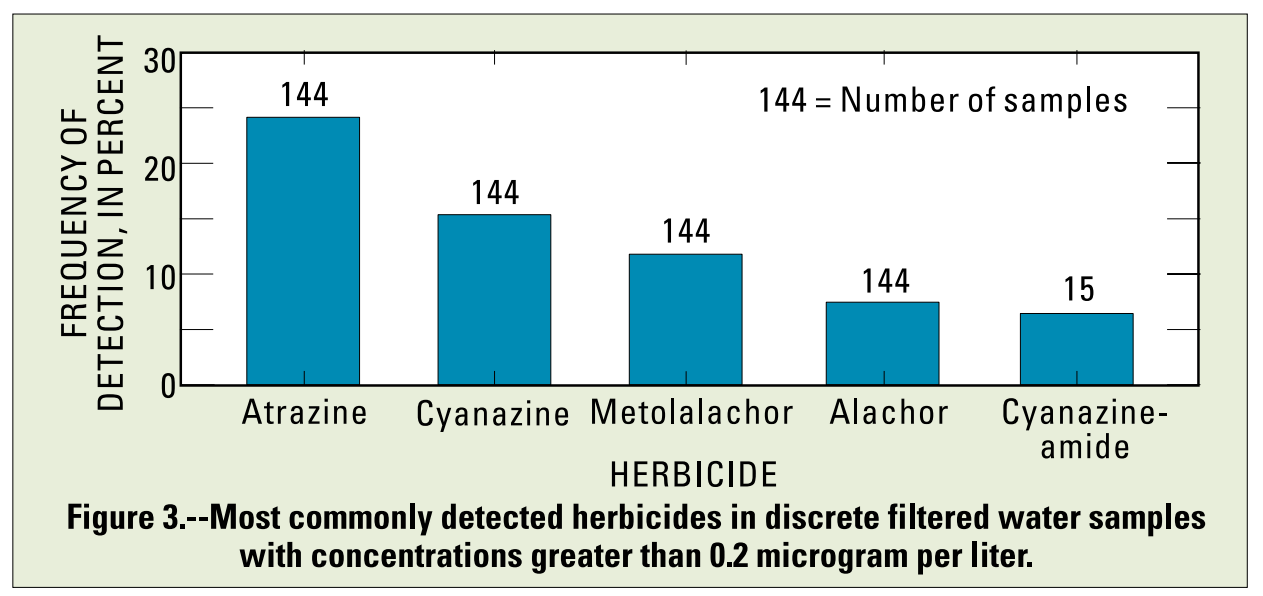

U. S. Department of the Interior

USGS Fact Sheet 066-00

U.S. Geological Survey

May 2000 

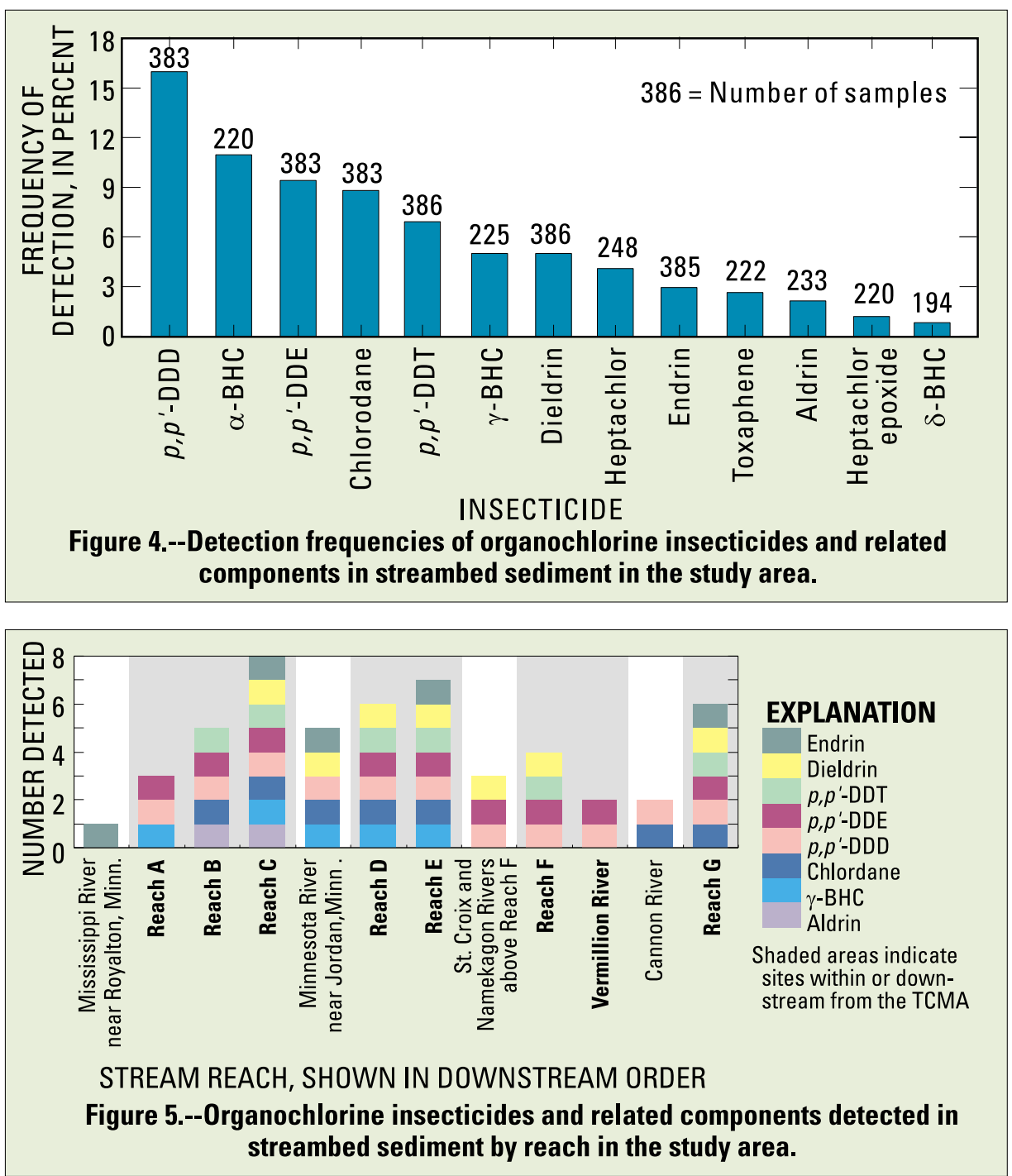

generally are below levels considered harmful to humans and aquatic life by the U.S. Environmental Protection Agency.

-James D. Fallon

\section{References}

Aspelin, A.L., 1994, Pesticide industry sales and usage-1992 and 1993 market estimates: U.S. Environmental Protection Agency Report 733-K94-001, 33 p.

Capel, P.D., Lin, M., and Wotzka, P.J., 1998, Wet atmospheric deposition of pesticides in Minnesota, 1989-94: U.S. Geological Survey WaterResources Investigations Report 97 4026, $42 \mathrm{p}$.

Creason, J.R., and Runge, C.F., 1992, Use of lawn chemicals in the Twin Cities: University of Minnesota Water
Larson, S.J., Capel, P.D., and Majewski, M.S., 1997, Pesticides in surface waters-Distribution, trends, and governing factors: Chelsea, Michigan, Ann Arbor Press, 373 p.

Majewski, M.S., and Capel, P.D., 1995, Pesticides in the atmosphereDistribution, trends, and governing factors: U.S. Geological Survey OpenFile Report 94-506, 191 p.

Miltner, R.J., Baker, D.B., Speth, T.F., and Fronk, C.A., 1989, Treatment of seasonal pesticides in surface waters: Journal of American Water Works Association, v. 81, no. 1, p. 43-52.

Nowell, L.H., and Resek, E.A., 1994, National standards and guidelines for pesticides in water, sediment, and aquatic organisms-Application to water-quality assessments, in Ware, G.W., ed., Reviews of Environmental Contamination and Toxicology: New York, Springer-Verlag, v. 140, p. 1164.

Sine, C., ed., 1993, 1993 Farm Chemical Handbook: Willoughby, Ohio, Meister Publishing Company, variously paged.

U.S. Environmental Protection Agency, 1994, Drinking water regulations and health advisories: U.S. Environmental Protection Agency, $18 \mathrm{p}$.

Whitmore, R.W., Kelly, J.E., and Reading, P.L., 1992, National home and garden pesticide use survey-Executive summary, results, and recommendations: Research Triangle Institute, Final report, RTI/1500/1701f, $140 \mathrm{p}$.

Wotzka, P.J., Lee, J., Capel, P.D., and Ma, Lin, 1994, Pesticide concentrations and fluxes in an urban watershed, in American Water Resources Association National Symposium on Water Quality, Chicago, Illinois, November, 1994, p. 135-145.

\footnotetext{
For more information contact: UMIS NAWQA Coordinator U.S. Geological Survey 2280 Woodale Drive

Mounds View, Minnesota 55112 Phone (612) 783-3100

http://wwwmn.cr.usgs.gov/umis
} 